Original Research Paper

\title{
Physical, Chemical, Microbiological and Parasitological Parameters in a Composting System of Vegetable Solid Residues
}

\author{
${ }^{1}$ Francisco Rafael Martins Soto, ${ }^{1}$ Maira Oliveira Silva, ${ }^{1}$ Ramieri Moraes, \\ ${ }^{1}$ Jéssica Vilela da Cruz, ${ }^{1}$ Jéssica Priscila Cavalcanti, ${ }^{1}$ Fernanda Alves da Silva, \\ ${ }^{1}$ Laine Rodrigues Lima, ${ }^{1}$ Elizabeth Soares de Jesus, ${ }^{2}$ Sérgio Santos de Azevedo, \\ ${ }^{3}$ Iolanda Cristina Silveira Duarte, ${ }^{3}$ Mônica Aparecida de Almeida and ${ }^{1}$ Sandro Eugênio Pereira Gazzinelli \\ ${ }^{I}$ Federal Institute of Education, Science and Technology of São Paulo, Campus Roque-SP, Brazil \\ ${ }^{2}$ Federal University of Campina Grande- PB, Brazil \\ ${ }^{3}$ Federal University of São Carlos-Campus Sorocaba-SP, Brazil
}

Article history

Received: 16-06-2015

Revised: 06-10-2015

Accepted: 20-11-2015

Corresponding Author:

Francisco Rafael Martins Soto

Federal Institute of Education,

Science and Technology of São

Paulo, Campus Roque-SP, Brazil

Tel: +55(11)4784-9470

Email: sotofrm@ifsp.edu.br

\begin{abstract}
This work aimed to evaluate the physical, chemical, microbiological and parasitological parameters in a composting system of Vegetable Solid Residues (VSR). The work was carried out during four months and was constituted of a compost bed of $12 \mathrm{~m}^{3}$ of volume and the proportion used for its filing was of 6:1 (VSR: Sawdust). For the analysis of the microbiological and parasitological parameters 16 sample collections were carried out for each parameter, at weekly intervals. The presence of Total Coliforms (TC), Thermotolerant Coliforms (TTC) and Intestinal Parasite Eggs (IPE). Regarding the physical and chemical parameters were analyzed: Temperature, $\mathrm{pH}$ and the Carbon and Nitrogen Relation (CNR). For the physical and chemical parameters the results revealed that there was a reduction in the CNR, with the final value of 14 . The temperature presented little increase in the first five weeks, with the average value of $38.98^{\circ} \mathrm{C}$ and its stabilization in the last week with average value of $29.3^{\circ}$. The $\mathrm{pH}$ oscillated between neutrality to slightly acid. There was no reduction in the TC, but for the TTC there was a decrease in its count of $98.54 \%$. In relation to the IPE, the composting system was capable of inactivating and eliminating them.
\end{abstract}

Keywords: pH, Temperature, Carbon Nitrogen Relation, Intestinal Parasite Eggs, Coliforms

\section{Introduction}

One of the main hindrances to the agroindustry development is that the processing of vegetables in various parts of the world is associated to a significant quantity of Solid Vegetable Residues (SVR) which are generated by the activity, with a good portion starting to be produced in the productive system, related mainly to the absence or low application of good production practices (Lin et al., 2011). Good vegetable production practices must be related mainly to preventive measures that minimize microbial contamination of these products and the appropriate destination SVR by efficient processes and cost (Santos et al., 2012).
The inadequate destination of the SVR generates impact which causes damage to the environment and to public health. The water contaminated by fecal matter of human origin, for example, used in the irrigation of vegetable gardens, contributes to the contamination of the vegetable leaves by bacteria and intestinal parasite eggs (Falavigna et al., 2005), which accelerates its decomposition and increases the production SVR, in addition to negative implications to public health.

The majority of the SVR is disposed in the environment or used in animal feed, without any treatment, what generates legal restrictions for such practice (Miguel et al., 2008).
Science

Publications
C 2015 Francisco Rafael Martins Soto, Maira Oliveira Silva, Ramieri Moraes, Jéssica Vilela da Cruz, Jéssica Priscila Cavalcanti, Fernanda Alves da Silva, Laine Rodrigues Lima, Elizabeth Soares de Jesus, Sérgio Santos de Azevedo, Iolanda Cristina Silveira Duarte, Mônica Aparecida de Almeida and Sandro Eugênio Pereira Gazzinelli. This open access article is 
The maintenance of non-treated SVR in the soil's surface makes it difficult for the microbial action to occur due to the reduced contact with the soil, resulting in a slower decomposition (Salces et al., 2013). It is highlighted that with the constant input of residues, a continuous production of organic compounds of low molecular mass is possible to occur, being its effect continuous on the fertility (Pavinato and Rosolem, 2008). Furthermore, SVR left on the soil's surface may also reduce the acidity and reduce the effect of the aluminum (Amaral et al., 2000).

Among the expected practices for the treatment of SVR, the process of composting to the solid residues by the agroindustry, has demonstrated satisfactory results, with the production of a bio-fertilizer of economic and environmental value and an innocuous product to public health and to the environment (Giannakis et al., 2014).

This process has as definition a controlled, exothermic and bio-oxidative decomposition of materials of organic origin by native microorganisms in a humid, heated and aerobic environment, with carbon dioxide, water, minerals and stabilized organic matter production, defined as compound (Barreira et al., 2006).

This compound when used in the soil offers agronomic benefits, such as elevation of the $\mathrm{pH}$, reduction of the potential acidity and the rise in the availability of macronutrients, besides representing a benefit of social order, due to the final disposal becoming less impacting on the environment (Rodrigues et al., 2011).

In an investigation which evaluated the temperature's influence in the composting process of home residues on the reduction of Escherichia coli, Salmonella sp., helminth eggs and enteric viruses in addition to the heterotrophic bacteria count, indicated oscillation in the $E$. coli and heterotrophic bacteria count, even after the thermophilic stage. On the other hand, the presence of Salmonella sp., enteric viruses or viable helminth eggs, at the end of the process (Heck et al., 2013).

In a system which involved the treatment of bovine manure by composting contaminated by Shigatoxigenic Escherichia coli, the very same was capable of eliminating the microorganism reducing the risk of environmental contamination and dissemination of the pathogen (Gonçalves and Marin, 2007).

The composting process of chicken carcasses also proved to be efficient in the elimination or in the reduction of microorganisms such as Salmonella and thermotolerant coliforms, at compatible levels with the ones demanded by the legislation (Sanchuki et al., 2011; Paiva et al., 2012).

This work aimed to evaluate the physical and chemical, microbiological and parasitological parameters in a composting system of vegetable solid residues.

\section{Materials and Methods}

The work was carried out during four months, in the period between 25th August to the 7th December 2014. For the construction of the composting system, it was constituted of a compost bed in built in masonry (cement block) $0.8 \mathrm{~m}$ high, $1.5 \mathrm{~m}$ wide and $10 \mathrm{~m}$ length, totalizing a volume of $12 \mathrm{~m}^{3}$. The flooring was made impermeable with concrete to prevent the contamination due to the leachate production, which was retained in a tank with its bottom water proofed by plastic sheeting.

The proportion used for the filling of the compost bed was of 6:1 (VSR: Sawdust) (Maragno et al., 2007). The sawdust was used in order to achieve the desired characteristics for the development of the composting process, which are usually denominated as fillers or carbon sources. The sawdust was added in order to adjust humidity, carbon/nitrogen ratio or pasta texture in composting.

After the filling of the compost bed, no interventions occurred there for 60 days and after this period weekly turnings with the use of common shovels for the oxygenation of the system up to its complete stabilization were performed (Pereira Neto, 2007).

For the analysis of the microbiological and parasitological parameters, 16 sample collections were carried out for each parameter, with weekly intervals, during 105 days, being the first collection carried out in the first day of implantation of the compost bed.

The presence of Total Coliforms (TC) and Thermotolerant Coliforms (TTC) and Intestinal Parasite Eggs (IPE) were investigated in the composting. For the research of TC and TTC a collection of composted material was carried out in various points of the system and was used to inoculate the culture media which determined the presence of bacteria. The samples were stored in polyethylene aseptic packaging and transported under refrigeration, the same day, to the Microbiology Laboratory of the Federal Institute of Science and Technology of São Paulo-São Roque Campus (IFSPSRQ) where they were processed.

The microbiological analyses were performed with the use of the Vanderzant and Splittstoesser (1992) technique; and Silva et al. (2007). The samples were diluted from the dilution of $10^{-1}$, plated in $10 \mathrm{~mL}$ of the sample in three tubes containing $10 \mathrm{~mL}$ of Lauryl broth double concentration Durhan tubes; $1.0 \mathrm{~mL}$ of the sample in three tubes with $10 \mathrm{~mL}$ Lauryl broth simple concentration and $0.1 \mathrm{~mL}$ in tubes with $10 \mathrm{~mL}$ of Lauryl broth simple concentration.

The tubes were incubated at $35^{\circ} \mathrm{C} \pm 1^{\circ} \mathrm{C}$ during 24 to $48 \mathrm{~h}$. After this period, Durham tubes which presented gas in their interior were considered positive and were compared to the combinations present in the Most 
Probable Number (MPN) table for TC. For the detection and quantification of FC, with the use of an inoculation loop, aliquots of the positive tubes were removed and were reprocessed to a tube containing $10 \mathrm{~mL}$ of EC Broth with Durham and incubated in kiln at $45^{\circ} \pm 2^{\circ} \mathrm{C} / 24-48 \mathrm{~h}$. After this period, the presence of $\mathrm{FC}$ was confirmed by the presence of gas in the Durham tube and compared to the MPN table for FC.

For the investigation of the IPE and its posterior viability samples of approximately $100 \mathrm{~g}$ were collected in various points of the composting system and were packed in polyethylene bags in the collection site and the material was initially taken for investigation of the IPE to the Parasitology Laboratory of the IFSP-SRQ.

Posteriorly, for the evaluation of the viability of the IPE found, the material was processed in the Parasitology Laboratory of the Federal University of Minas Gerais.

For the verification of the presence or not of IPE in the composting process the spontaneous sedimentation technique was used (Hoffman et al., 1934). About 250 $\mathrm{mL}$ of distilled water were added to the samples and they were posteriorly filtered in four fold gauze and left to rest for $24 \mathrm{~h}$. The following day, the supernatant liquid was discarded and the final $30 \mathrm{~mL}$ were transferred to a $50 \mathrm{~mL}$ sedimentation glass.

From the sediment obtained at the end of the tube were collected three drops, using a plastic pipette and they were placed between the glass slides. When necessary, in order to differentiate the protozoan cysts, lugol was added to the analyzed sample. Each sample was analyzed in triplicate, using an optical microscope, with a 10x objective and a scanning examination was carried out for the finding and identification of the parasites. The confirmation of the parasitic structures was performed using a 40x objective. The parasitic forms were identified using the parasitology identification key (OMS, 1991).

The evaluation of the viability of the IPE was carried out using the rapid staining technique (Galván et al., 1998), which was based on the use of biological dyes to detect the changes of permeability of the vitelline membrane of the IPE. These exchanges are related to the embrionary metabolism and to the viability, seen that a viable egg is impermeable to certain types of dye and, however do not stain. Whereas a IPE which has lost its viability is permeable and stains. Thus, for the verification of the viability of the IPE found, $10 \mathrm{~g}$ of the samples in which were found IPE were weighed and $100 \mathrm{~mL}$ of distilled water were added to them. The solution was filtered through an eight $\mu \mathrm{m}$ porosity membrane and $47 \mathrm{~mm}$ of diameter. After that, the membrane was scraped and the solids were collected with a solution of zinc sulphate (density of 1.21). The membrane and the spatula were washed with the same solution and centrifuged at a $2500 \mathrm{rpm}$ during three minutes. The supernatant was filtered again with an eight $\mu \mathrm{m}$ porosity membrane and $25 \mathrm{~mm}$ of diameter. A drop of dye was added to the final material obtained (Trypan Blue, Eosin Y or Safranin O) and a drop of glycerol to increase the transparency of the sample. The viable or not IPE were counted using 10x and 40x objectives.

The following physical and chemical parameters were analyzed in the composting system: Temperature, $\mathrm{pH}$ and the Carbon to Nitrogen Ratio (CNR).

The temperature was measured daily at a predetermined time, from day zero o the 105 th day of the system, with the introduction of the thermometer during three minutes in the interior of the composting system. For the investigation of the $\mathrm{pH}$ and the CNR, sixteen sample collections were performed for each parameter, with weekly intervals and the first collection was carried out on the first day of implantation. The analyses were carried out in the Chemistry Laboratory of the IFSP- SRQ. In relation to the determination of the $\mathrm{pH}$ the calcium chloride reaction test was used $\left(\mathrm{CaCl}_{2} 0.01 \mathrm{~mol} \mathrm{~L}^{-1}\right)$ (Raij et al., 2001). For the determination of the carbon/nitrogen ration, the titlemetry analytical technique was used, followed by titration and posterior calculation (Szakacs, 2003).

For the statistical treatment of the results a correlation matrix between the variables was performed between the variables IPE, FC, $\mathrm{pH}, \mathrm{CNR}$ and temperature, with the determination of the Pearson's correlation coefficient (r) and respective confidence interval of $95 \%$ (CI 95\%) and coefficient of determination $\left(\mathrm{R}^{2}\right)$ (Zar, 1999). The analyses were carried out with the Bio Estat 5.03 statistic program, with level of significance $5 \%$.

\section{Results and Discussion}

In Table 1, the results obtained are presented in relation to the physical and chemical parameters in the composting system of VSR.

In relation to the average temperature parameter, it was observed that in the first 28 days it was of $38.98^{\circ} \mathrm{C}$, slightly superior in the period from 29 to 77 days in which it was of $34.52^{\circ} \mathrm{C}$ and evidenced the exothermic stage and as a consequence there was a high enzyme production in the composting system at the beginning of the process. Such result was similar to what Awasthi et al. (2015), observed in an experiment in which different sources of organic matter were used for composting. However, Muntjeer et al. (2014), also investigating the temperature in the composting of VSR, detected temperature values which reached up to $65^{\circ} \mathrm{C}$ in the beginning of the system, different from the results obtained in this study. 
Table 1.Physical and chemical parameters obtained in the composting system of vegetable solid residues in relation to temperature $\left({ }^{\circ} \mathrm{C}\right)$, carbon/nitrogen ratio and $\mathrm{pH}$, expressed numerically, since the day zero up to 105 days

\begin{tabular}{lllll}
\hline Day & Week & Temperature & CNR & $\mathrm{pH}$ \\
\hline Zero & 01 & 38.6 & 29 & 6.73 \\
07 & 02 & 42.7 & 8 & 6.73 \\
14 & 03 & 39.2 & 24 & 7.36 \\
21 & 04 & 37.7 & 19 & 6.73 \\
28 & 05 & 36.7 & 25 & 6.94 \\
35 & 06 & 32.2 & 17 & 6.51 \\
42 & 07 & 34.3 & 23 & 6.93 \\
49 & 08 & 38.6 & 13 & 6.56 \\
56 & 09 & 35.3 & 12 & 7.11 \\
63 & 10 & 32.4 & 12 & 6.01 \\
70 & 11 & 34.2 & 12 & 6.19 \\
77 & 12 & 34.7 & 9 & 5.44 \\
84 & 13 & 34.9 & 12 & 5.75 \\
91 & 14 & 30.9 & 12 & 6.15 \\
98 & 15 & 29.3 & 5.77 \\
105 & 16 & 29.3 & 6.32 \\
\hline
\end{tabular}

$\mathrm{CNR}=$ Carbon to Nitrogen Ratio

During the last four weeks was detected a reduction in the values with the average result of $31.1^{\circ} \mathrm{C}$, indicating its stabilization and proximity to the environmental temperature.

The CNR was high on day zero with a value of 29 , what is characteristic of composting systems with organic matter rich in vegetable fiber (Guo et al., 2013). In the following week, the result was inconsistent, with value of eight. As for between the third and seventh week, the values oscillated between 17 and 25, with an average result of 21.6, indicating a small carbon consumption by the microbiota established in the composting and beginning of the stabilization of the organic matter. Pepe et al. (2013), reported that in this stage of composting there is a predominance of pectinolytic, mylolytic and cellulolytic bacteria, capable of degrading the vegetable fiber. In the period between the 8th and 16th week, the results oscillated between 9 and 14, with average value of 12 . Such results evidenced the carbon consumption by the microorganisms with a reduction of $58,62 \%$, when compared to the first week and the stabilization of the organic matter, what was confirmed by Cui and Yang (2014) where a CNR was detected in composting of SVR with a value of 12.08. However, in a similar experiment also with the use of SVR, Varma and Kalamdhad (2014), observed at the end of their work a CNR of 19.

In relation to the $\mathrm{pH}$, in the first eight weeks, the results oscillated between neutrality and slightly acid. Between the 9th and 16th week, the $\mathrm{pH}$ remained slightly acid, with average value of 6.09 , being then established a favorable condition for the acidophilus bacteria. The system's $\mathrm{pH}$ did not present tendency to alkalinity. These results were controversial to those of Topčagić et al. (2013), who found in composting of organic home residues associated to poultry manure in which $\mathrm{pH}$ values reached results of up to 8.75 , what the authors believe that the mixture of different sources of organic matters in the composting may be decisive for the broad variation of the $\mathrm{pH}$ values.

In Table 2, are presented the results obtained in the composting system of vegetable solid residues in relation to the parasitological and microbiological parameters.

For the investigation of $\mathrm{TC}$, the results revealed that the composting system was incapable of reducing their number and maintained during all the evaluated

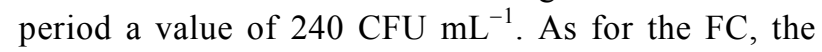
group of bacteria with the greatest environmental and sanitary importance, it was observed that between the first and fourth week, the value was maintained at $240 \mathrm{CFU}$ $\mathrm{mL}^{-1}$, however, from the fifth week these results started

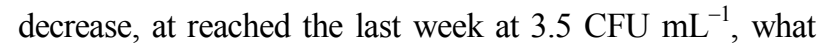
represented a reduction of $98.54 \%$, when compared to the first week. These results indicate that the composting system was capable of reducing the FC, thus making the VSR a product with a low environmental and sanitary impact. Avery et al. (2012) described that composting systems are capable of reducing or eliminating bacteria of the thermotolerant group with pathogenic potential.

It is worth mentioning that, that exclusively in the 8th and 13 th week, there was an inconsistency in the FC values with results of 240 UFC $\mathrm{mL}^{-1}$. These results may be related to the possible contamination of the temporary system by birds or insects arthropods which could have their bodies FC. In future work 
similar to this, a protection against these animals must be provided, as for example the use of screens in the composting system.

Regarding the IPE, in the first five weeks, the values oscillated from zero to 100 . As from the 5 th Week a decrease in their count was detected and arriving at the 13th week, with the absence of IPE in the composting system. These results were also confirmed by Koné et al. (2007), in a composting system, coming from a tropical climate, was capable of reducing intestinal parasite eggs to less than one viable egg per gram of compound. In relation to the investigation of the viability of the IPE in the weeks in which they were detected, the results showed that despite being present, they were unviable, indicating the capability of the composting system of inactivating the IPE. Such information is important for the public health, for even if its present in 11 of the 16 evaluated weeks, with counts varying from one to 100 , they were incapable of causing parasitic infections in humans and animals.
In Table 3, are presented the results of statistic correlation obtained between the physical and chemical, microbiological and parasitic parameters.

Regarding the analysis of the correlation between the IPE and the physical and chemical parameters, there was association for the $\mathrm{pH}$ and $\mathrm{CNR}$.

For the FC and the physical and chemical parameters, there was association for the temperature. Such result reinforced the importance of the temperature to reduce, increase and maintain the FC concentration, what was confirmed by Patel et al. (2015) where the high temperature, above $50^{\circ} \mathrm{C}$ in the composting system was a determining to reduce the $\mathrm{FC}$ concentration.

The variable TC was not evaluated because the same value (240) was observed in all the weeks.

In the correlation analysis between the physical and chemical parameters, (Table 3) there was association between $\mathrm{pH}$ and $\mathrm{CNR}(\mathrm{p}=0.0144)$ and $\mathrm{pH}$ and temperature $(p=0.0316)$. These results highlighted the strong interaction and dynamism between the physical and chemical parameters in the composting process. However, it was not found statistical association between CNR and temperature (Table 3).

Table 2. Microbiological and parasitological parameters obtained in the composting system of vegetable solid residues in relation to thermotolerant and total coliforms and intestinal parasite eggs

\begin{tabular}{llcl}
\hline Day & Week & FC (CFU/mL) & IPE(NC) \\
\hline Zero & 01 & 240.0 & Zero \\
07 & 02 & 240.0 & 02 \\
14 & 03 & 240.0 & 100 \\
21 & 04 & 240.0 & 100 \\
28 & 05 & 110.0 & 100 \\
35 & 06 & 21.0 & 12 \\
42 & 07 & 15.0 & 16 \\
49 & 08 & 240.0 & 20 \\
56 & 09 & 2.1 & 04 \\
63 & 10 & 12.0 & 06 \\
70 & 11 & 5.3 & 01 \\
77 & 12 & 5.3 & 02 \\
84 & 13 & 240.0 & Zero \\
91 & 14 & 4.2 & Zero \\
98 & 15 & 3.5 & Zero \\
105 & 16 & 3.5 & Zero \\
\hline
\end{tabular}

$\mathrm{CFU}=$ Colony Forming Units, TC = Total Coliforms, FC = Fecal Coliforms, IPE = Intestinal Parasite Eggs, CFU = Colony Forming Units, $\mathrm{mL}=$ milliliters, $\mathrm{NC}=$ Numerical Count

Table 3. Correlation matrix for microbiological, parasitological, physical and chemical parameters in a compositing system of vegetable solid residues

\begin{tabular}{lll}
\hline Comparisons & $\mathrm{R}^{2}$ & $\mathrm{p}$-value \\
\hline IPE and FC & 0.1793 & 0.1020 \\
IPE and pH & 0.3172 & 0.0230 \\
IPE and CNR & 0.3168 & 0.0230 \\
IPE and temperature & 0.1566 & 0.1290 \\
FC and pH & 0.1242 & 0.1810 \\
FC and CNR & 0.0643 & 0.3430 \\
FC and temperature & 0.6434 & 0.0002 \\
pH and CNR & 0.3572 & 0.0144 \\
pH and temperature & 0.2892 & 0.0316 \\
RCN and temperature & 0.0629 & 0.3490 \\
\hline
\end{tabular}

$\mathrm{R}^{2}=$ determination coefficient, $\mathrm{FC}=$ Fecal Coliforms, IPE = Intestinal Parasite Eggs, CNR = Carbon to Nitrogen Ratio 


\section{Conclusion}

Under the conditions that the work was conducted, it can be concluded that the composting system:

- As from 35 days of treatment SVR, FC decreased on average $90 \%$

- There was no reduction of the total coliforms, however, regarding the fecal coliforms; there was a $98.54 \%$ reduction in its count in the final of work

- For the investigation of the intestinal parasite eggs, the composting system was capable of inactivating and eliminating them

- Reduction in the carbon to nitrogen ratio on average $50 \%$ after 35 days of treatment SVR

- The temperature presented little increase in the first five weeks, with the average value of $38.98^{\circ} \mathrm{C}$ and its stabilization in the last week with average value of $29.3^{\circ}$

- In relation to the $\mathrm{pH}$ it oscillated between neutrality to slightly acid

\section{Acknowledgement}

We are grateful to the Dean of Extension of the Federal Institution of Education, Science and Technology of São Paulo and to the National Council for Scientific and Technological Development, for the financial support provided to the project.

\section{Author's Contributions}

Francisco Rafael Martins Soto: Design and coordinated the study, writing and the final art work.

Maira Oliveira Silva, Ramieri Moraes, Jéssica Vilela da Cruz, Jéssica Priscila Cavalcanti, Fernanda Alves da Silva, Laine Rodrigues Lima, Mônica de Almeida and Elizabeth Soares de Jesus: Responsible for the collection of samples, datas and laboratorial essays.

Sérgio Santos de Azevedo and Iolanda Cristina Silveira Duarte: Interpreted the data, statically analysis and organized the study by reviewing it critically.

Sandro Eugênio Pereira Gazzinelli: Responsible for the investigation of the intestinal parasite eggs and its posterior viability samples.

\section{Ethics}

The authors declare that this is an original research and do not have any ethical issues or copyrights conflict.

\section{References}

Amaral, A.S., V. Spader, I. Anghinoni and E.J. Meurer, 2000. Resíduos vegetais na superfície do solo afetam a acidez do solo e a eficiência do herbicida flumetsulam. Cienc. Rural, 30: 789-794. DOI: $10.1590 / \mathrm{S} 0103-84782000000500008$
Awasthi, M. K., A.K. Pandey, P.S. Bundela and J. Khan, 2015. Co-composting of organic fraction of municipal solid waste mixed with different bulking waste: Characterization of physicochemical parameters and microbial enzymatic dynamic. Bioresource Technol., 182: 200-207. DOI: $10.1016 /$ j.biortech.2015.01.104

Avery, L.M., P. Booth, C. Campbell, D. Tompkins and R.L. Hough, 2012. Prevalence and survival of potential pathogens in source-segregated green waste compost. Sci. Total Environ., 431: 128-138. DOI: 10.1016/j.scitotenv.2012.05.020

Barreira, L.P., A.P. Junior and M.S. Rodrigues, 2006. Usinas de compostagem do Estado de São Paulo: Qualidade dos compostos e processos de produção. Eng. Sanit. Ambient., 11: 385-393. DOI: $10.1590 / \mathrm{S} 1413-41522006000400012$

Cui, X. and Y.C. Yang, 2014. Effect of different mass ratios of straws and vegetable wastes on cocomposting. Adv. Mater. Res., 1010: 922-927. DOI: 10.4028/www.scientific.net/AMR.1010-1012.922

Falavigna, L.C., C.B.R. Freitas, G.C. Melo, L.N.S.M. Araújo and A.L.F. Guilherme, 2005. Qualidade de hortaliças comercializadas no noroeste do Paraná, Brasil. Parasitol. Latinoam., 60: 144-149. DOI: $10.4067 / \mathrm{S} 0717-77122005000200007$

Galván, M., J. Victorica and N. Rojas, 1998. Potential viability of helminth eggs in wastewater assessed by vital staining. Proceedings of the IAWQ 19th Biennial International Conference, (BIC' 98), Vancouver, Canada, pp: 32-26.

Giannakis, G.V., N.N. Kourgialas, N.V. Paranychianakis, N.P. Nikolaidis and N. Kalogerakis, 2014. Effects of municipal solid waste compost on soil properties and vegetables growth. Compost Sci. Util., 22: 116-131. DOI: $10.1080 / 1065657 X .2014 .899938$

Gonçalves, V.P. and J.M. Marin, 2007. Fate of non O157 Shiga toxigenic Escherichia coli in composted cattle manure. Arq. Bras. Med. Vet. Zootec., 59: 825-831. DOI: $10.1590 /$ S0102-09352007000400001

Guo, R., G. Li, T. Jiang, F. Schuchardt and T. Chen et al., 2012. Effect of aeration rate, $\mathrm{C} / \mathrm{N}$ ratio and moisture content on the stability and maturity of compost. Bioresource Technol., 112: 171-178. DOI: 10.1016/j.biortech.2012.02.099

Heck, K., E.G. Marco, A.B.B. Hahn, M. Kluge and F.R. Spilki et al., 2013. Temperatura de degradação de resíduos em processo de compostagem e qualidade microbiológica do composto final. Rev. Bras. Eng. Agríc. Ambient., 17: 54-59.

DOI: $10.1590 / \mathrm{S} 1415-43662013000100008$

Hoffman, W.A., J.A. Pons and J.L. Janer, 1934. The sedimentation-concentration method in Schistosomiasismansoni. PR J. Public Health Trop. Med., 9: 281-298. 
Koné, D., O. Cofie, C. Zurbrügg, K. Gallizzi and D. Moser et al., 2007. Helminth eggs inactivation efficiency by faecal sludge dewatering and cocomposting in tropical climates. Water Res., 41: 4397-4402. DOI: 10.1016/j.watres.2007.06.024

Lin, J., J. Zuo, L. Gan, P. Li, F. Liu and K. Wang et al., 2011. Effects of mixture ratio on anaerobic codigestion with fruit and vegetable waste and food waste of China. J. Environ. Sci., 23: 1403-1408. DOI: $10.1016 / \mathrm{S} 1001-0742(10) 60572-4$

Maragno, E.S., D.F. Trombin and E.O. Viana, 2007. O Uso da serragem no processo de minicompostagem. Eng. Sanit. Ambient., 12: 355- 360. DOI: $10.1590 / \mathrm{S} 1413-41522007000400001$

Miguel, A.C.A., S. Albertini, G.F. Begiato, J.R.P.S. Dias and M.H.F. Spoto, 2008. Aproveitamento agroindustrial de resíduos sólidos provenientes do melão minimamente processado.Ciênc. Tecnol. Aliment., 28: 733-737. DOI: $10.1590 / \mathrm{S} 0101-20612008000300033$

Muntjeer, A., A.A. Kazmi and A. Naseem, 2014. Study on effects of temperature, moisture and $\mathrm{pH}$ in degradation and degradation kinetics of aldrin, endosulfan, lindane pesticides during full-scale continuous rotary drum composting. Chemosphere, 102: $68-75$.

DOI: $10.1016 /$ j.chemosphere.2013.12.022

OMS, 1991. Pranchas para diagnóstico de parasitas intestinais. Organização Mundial de Saúde.

Paiva, E.C.R., A.T. Matos, M.A. Azevedo, R.T.P. Barros and T.D.R. Costa, 2012. Avaliação da compostagem de carcaças de frango pelos métodos da composteira e de leiras estáticas aeradas. Eng. Agríc., 32: 961-970. DOI: $10.1590 / \mathrm{S} 0100-69162012000500015$

Patel, J.R., I. Yossa, D. Macarisin and P. Millner, 2015. Physical covering for control of escherichia coli O157:H7 and Salmonella spp. in static and windrow composting processes. Applied Environ. Microbiol., 81: 2063-2074. DOI: 10.1128/AEM.04002-14

Pavinato, P.S. and C.A. Rosolem, 2008. Disponibilidade de nutrientes no solo-decomposição e liberação de compostos orgânicos de resíduos vegetais. R. Bras. Ci. Solo, 32: 911-920. DOI: $10.1590 / \mathrm{S} 0100-06832008000300001$

Pepe, O., V. Ventorino and G. Blaiotta, 2013. Dynamic of functional microbial groups during mesophilic composting of agro-industrial wastes and free-living $\left(\mathrm{N}_{2}\right)$-fixing bacteria application. Waste Manage., 33: 1616-1625. DOI: 10.1016/j.wasman.2013.03.025

Pereira Neto, J.T., 2007. Manual de Compostagem, Processo de Baixo Custo. 1st Edn., UFV, ViçosaMG, pp: 81 .
Raij, B.V., J.C. Andrade, H. Cantarela and J.A. Quaggio, 2001. Análise Química para Avaliação da Fertilidade de Solos Tropicais. 1st Edn., Instituto Agronômico, Campinas, ISBN-10: 8585564059, pp: 285.

Rodrigues, P.N., P.M. Rolim, E.B. Neto, R.N.T. Costa and E.M.R. Pedrosa et al., 2011. Efeito do composto orgânico e compactação do solo no milho e nutrientes do solo. Rev. Bras. Eng. Agríc. Ambient., 15: 788-793. DOI: 10.1590/S1415-43662011000800004

Salces, B.M., X. Gómez, A. Morán and M.C.G. González, 2013. Anaerobic co-digestion of livestock and vegetable processing wastes: Fibre degradation and digestate stability. Waste Manage., 33: 1332-1338. DOI: 10.1016/j.wasman.2013.02.021

Sanchuki, C.E., C.R. Soccol, J.C. Carvalho, V.T. Soccol and C.N.A.L. Woiciechowski, 2011. Evaluation of poultry litter traditional composting process. Braz. Arch. Biol. Techn., 54: 1053-1058. DOI: $10.1590 / \mathrm{S} 1516-89132011000500024$

Santos, H.D.S., M.C.S. Muratori, A.L.A. Marques, V.C. Alves and F.D.C. Cardoso Filho et al., 2012. Evaluation of the efficacy of sodium hypochlorite in sanitization of lettuce (Lactuca sativa). Rev. Inst. Adolfo Lutz, 71: 50-60.

Szakacs, G.G.J., 2003. Sequestro de carbono nos solos: Avaliação das potencialidades dos solos arenosos sob pastagens. Universidade de São Paulo, Piracicaba.

Silva, N., V.C.A. Junqueira and N.F.A. Siveira, 2007. Manual de Métodos de Análises Microbiológicas de Alimentos. 3rd Edn., Varela, São Paulo, ISBN-10: 8577590038, pp: 536.

Topčagić, M., I. Petric, E. Avdihodžić, N.I. Avdić and S. Elezović, 2013. Effect of poultry manure addition on the aerobic composting process of organic fraction of municipal solid waste. Technol. Acta, 6: 39-50.

Vanderzant, C. and D.F. Splittstoesser, 1992. Compendium of Methods for the Microbiological Examination of Foods. 3rd Edn., American Public Health Association, Washington, ISBN-10: 0875531733, pp: 1219.

Varma, V.S. and A.S. Kalamdhad, 2014. Stability and microbial community analysis during rotary drum composting of vegetable waste. Int. J. Rec. Org. W. Agric., 3: 52-60. DOI: 10.1007/s40093-014-0052-4

Zar, J.H., 1999. Biostatistical Analysis. 4th Edn., Prentice-Hall, Upper Saddler River, ISBN-10: 013081542X, pp: 663. 